\title{
Three are better than one: plasminogen receptors as cancer theranostic targets
}

Patrizia Ceruti ${ }^{1,2 \dagger}$, Moitza Principe ${ }^{1,2 \dagger}$, Michela Capello ${ }^{1,2}$, Paola Cappello $0^{1,2}$ and Francesco Novelli $i^{1,2^{*}}$

\begin{abstract}
Activation of plasminogen on the cell surface initiates a cascade of protease activity with important implications for several physiological and pathological events. In particular, components of the plasminogen system participate in tumor growth, invasion and metastasis. Plasminogen receptors are in fact expressed on the cell surface of most tumors, and their expression frequently correlates with cancer diagnosis, survival and prognosis. Notably, they can trigger multiple specific immune responses in cancer patients, highlighting their role as tumor-associated antigens. In this review, three of the most characterized plasminogen receptors involved in tumorigenesis, namely Annexin 2 (ANX2), Cytokeratin 8 (CK8) and alpha-Enolase (ENOA), are analyzed to ascertain an overall view of their role in the most common cancers. This analysis emphasizes the possibility of delineating new personalized therapeutic strategies to counteract tumor growth and metastasis by targeting plasminogen receptors, as well as their potential application as cancer predictors.
\end{abstract}

Keywords: Annexin 2, Cytokeratin 8, Alpha-enolase, Plasminogen system, Plasminogen receptors, Cancer, Immunotherapy

\section{Introduction}

The plasminogen system is involved in tumor growth, invasion and metastasis [1-5]. Several proteins of this system have now been demonstrated to have a clinical value as diagnostic and prognostic markers in many types of cancer [6-11]. Overexpression of plasminogen receptors has been associated with poor prognosis, shorter patient survival and resistance to chemotherapy. Notably, this over-expression may lead to the production of autoantibodies in many types of cancers, which can be consequently used as tumor biomarkers. Moreover, most plasminogen system components are cell surface-expressed and therefore represent readily accessible targets for cancer therapy. This review aims to analyze the plasminogen receptors Annexin 2 (ANX2), Cytokeratin 8 (CK8) and alpha-Enolase (ENOA) in the most common tumors and to correlate their expression with specific immune responses and/or clinical outcomes.

\footnotetext{
* Correspondence: franco.novelli@unito.it

${ }^{\dagger}$ Equal contributors

${ }^{1}$ Center for Experimental Research and Medical Studies (CeRMS), Azienda Ospedaliera Città della Salute e della Scienza, Via Cherasco 15, Turin 10126, Italy

${ }^{2}$ Department of Molecular Biotechnology and Health Science, University of Turin, Turin, Italy
}

\section{() Biomed Central

(c) 2013 Ceruti et al., licensee BioiMed Central Ltd. This is an Open Access article distributed under the terms of the Creative Commons Attribution License (http://creativecommons.org/licenses/by/2.0), which permits unrestricted use, distribution, and reproduction in any medium, provided the original work is properly cited.

\section{The plasminogen system}

Plasminogen is a $90 \mathrm{kDa}$ glycoprotein produced by the liver and present in plasma and extracellular fluids [12-15]. It possesses seven structural domains: an $\mathrm{N}$-terminal activation peptide (1-77 aa), five kringle domains and a serine-protease domain (562-791 aa). The kringle domains mediate plasminogen binding to substrates and to cell surface receptors $[13,16]$ whereas the activation of plasminogen to plasmin is mediated by the proteolytic action of either tissue-type (tPA) or urokinase-type (uPA) plasminogen activators $[2,4,17,18]$. Plasmin is a serine protease with a broad-spectrum substrate, including fibrin, extracellular matrix components (laminin, fibronectin) and proteins involved in extracellular matrix degradation (matrix metalloproteinases, such as MMP3) [16,19-22]. Binding of plasminogen to surface receptors has profibrinolytic consequences: enhancement of plasminogen activation, protection of plasmin from its inhibitor a2-antiplasmin and enhancement of the proteolytic activity of cell-bound plas$\min [4,23-25]$. Proteolysis mediated by cell-associated plasmin contributes both to physiological processes, such as tissue remodeling and embryogenesis, and to pathophysiological processes, such as cell invasion, metastasis and inflammatory responses [2-4,26-28]. A noteworthy positive 
correlation exists between elevated levels of plasminogen activation and malignancy $[2,29]$.

Plasminogen receptors bind plasminogen by carboxyterminal lysines, and this common recognition motif results in a similar affinity of plasminogen for most of its receptors $(\mathrm{Kd} \approx 1 \mu \mathrm{M})$. Although many plasminogen receptors have been described so far [30-43], the most well-known plasminogen receptors shown to play a role in cancer are ANX2, CK8 and ENOA. Interaction of the plasminogen lysine binding sites with ENOA and CK8 is dependent upon recognition of three C-terminal lysines $[23,40]$. For ENOA, an additional internal plasminogen binding site, which includes Lys256, has been proposed [44]. On the other hand, ANX2 harbors internal amino acids that mimic $\mathrm{C}$-terminal lysines and therefore requires cleavage prior to binding plasminogen [45].

\section{Molecular features of plasminogen receptors}

ANX2 is a $36 \mathrm{kDa}$ peripheral membrane protein (p36) that belongs to the Annexin family, consisting of calciumdependent phospholipid-binding proteins with various membrane-related functions [46-48]. ANX2 either exists as a monomer, a heterodimer or a heterotetramer, the latter being composed of two copies of a $36 \mathrm{kDa}$ heavy chain (p36) and two copies of an $11 \mathrm{kDa}$ light chain (p11). Formation of the Anx2 heterotetramer facilitates its binding to the plasma membrane $[45,48,49]$.

CK8 is an intermediate filament protein that polymerizes with CK18 to form a component of the epithelial cytoskeleton [50]. In addition to its cytoplasmic localization it can also be expressed on the cell surface $[51,52]$ where it is localized to the blebs of the cell membrane and acts as a plasminogen receptor [53].

ENOA (2-phospho-D-glycerate hydrolase) was initially discovered as a metalloenzyme that catalyzes the dehydration of 2-phospho-D-glycerate (PGA) to phosphoenolpyruvate (PEP) in the glycolytic pathway [54,55]. In vertebrates, the enzyme has three different isoforms (alpha, beta, and gamma) codified by three independent loci. While ENOA is mostly ubiquitous, beta- and gamma-enolase are almost exclusively found in muscle and in neuronal tissues, respectively $[54,56,57]$. ENOA can form homo- or heterodimers, such as alpha-alpha, alpha-beta and alpha-gamma [58,59]. Both homo- and heterodimers can be expressed on the cell surface where they act as plasminogen receptors.

Interestingly ANX2, CK8 and ENOA amino acid sequences lack a transmembrane portion, and the mechanism by which they are displayed on the cell surface remains unknown. Several mechanisms have been proposed for the cell surface expression, including lipid binding followed by translocation to the outer membrane [60]; penetration and projection through the plasma membrane as a part of a protein complex [52,61]; and non-covalent association to the cell membrane after proteolytic release from cells into the extracellular space [62-64]. In the case of ANX2 and ENOA, post-translational modifications, such as acylation, acetylation, methylation and phosphorylation, particularly common in tumor cells, may also play a role [65-67].

\section{Expression and function of ANX2 in cancer}

ANX2 is physiologically expressed on the surface of epithelial cells, vascular endothelial cells and macrophages and is not only involved in plasminogen activation but also in many biological processes that include inflammation, cell proliferation, angiogenesis, cell-cell interactions and membrane bridgings, exocytosis and endocytosis, cell growth and apoptosis [48,68-73]. All these functions are due to its ability to interact with actin filaments in the cytoskeletal system, to locate proteases and other extracellular matrix components (plasminogen-plasmin-tPA) on the cell surface through tetramerization, or by acting as a major substrate for phosphorylation and as a second messenger of growth-mediating receptor [49]. Indeed, ANX2 is phosphorylated on Tyr23, Ser11 and Ser25 residues by c-Src, v-Src and Protein Kinase C (PKC), respectively [74-76] after activation of insulin receptor [77], insulin growth factor regulator [78], platelet-derived growth factor-R [79], fibroblast growth factor (FGF) or epidermal growth factor (EGF) [80]. Therefore, ANX2 may play a role as a second messenger for transduction of growth and differentiation.

During oncogenic transformation, ANX2 is usually upregulated and is a marker of aggressiveness in the majority of cancer types (Table 1) [68,81-101]. As a result, it is a valuable tool for cancer diagnosis. In fact, in hepato-cellular carcinoma (HCC), ANX2 has been proposed as a differential diagnostic marker, in combination with glypican-3 (GPC3), glutamine synthetase (GS) and heat shock protein 70 (HSP70) [65,85,86,90,93,98,100-104]. ANX2 downregulation has also been reported in certain cancers, such as laryngeal and esophageal squamous cell carcinoma, head and neck dysplasia [105-109], osteosarcoma [110] and prostate cancer [111-113] (Table 1). In osteosarcoma and oral carcinoma, ANX2 overexpression is generally associated with well-differentiated tumors and, in certain cases, ANX2 down-regulation was observed in poorly-differentiated cancer which may be due to its ability to promote differentiation independently from its plasminogen-binding function $[107,110]$. Indeed, in oral carcinoma two different groups have reported an increased expression of ANX2 in tumor tissue compared to the surrounding normal mucosa or mucosa from patients without oral cancer [100,107]. Rodrigo et al. also added a clinical correlation analysis in which the lower expression of ANX2 seemed to correlate with a poor prognosis. Even if these studies appear controversial, both groups reported that in poorly differentiated tumors, which usually correlate with a bad prognosis, ANX2 was down-regulated. We 
Table 1 Expression, immune response, clinical correlation and function of ANX2 in cancer

\begin{tabular}{|c|c|c|c|c|}
\hline Cancer tissue & Expression & $\begin{array}{l}\text { Immune } \\
\text { response }\end{array}$ & Clinical correlation & Function \\
\hline Bone & protein [110] & & & Metastasis [110] \\
\hline Brain & protein $[97,98]$ & & Diagnosis [98] & \\
\hline Breast & mRNA [99] & & & $\begin{array}{l}\text { Chemoresistance, Growth, Metastasis } \\
{[99,114-116,118]}\end{array}$ \\
\hline Colon & mRNA, protein $[86,89,96]$ & & Prognosis [86] & \\
\hline Gastric & protein [85] & & Prognosis [85] & \\
\hline Head and neck & $\begin{array}{l}\text { mRNA, protein [100] } \\
\text { [105-109] }\end{array}$ & $\operatorname{Ab}[119,120]$ & Prognosis [100] & \\
\hline $\begin{array}{l}\text { Hematopoietic } \\
\text { system }\end{array}$ & mRNA [95] protein $[68,91]$ & & & Growth, Metastasis $[68,91]$ \\
\hline Kidney & protein $[84,101]$ & & Survival, Prognosis [101] & Metastasis [121] \\
\hline Liver & $\begin{array}{l}\text { mRNA, protein } \\
{[88,90,92,93]}\end{array}$ & & $\begin{array}{l}\text { Diagnosis, Prognosis } \\
{[90,93,103]}\end{array}$ & \\
\hline Lung & protein [82] & $\mathrm{Ab}[122]$ & & Growth, Metastasis [117] \\
\hline Ovary & & $\mathrm{Ab}[123]$ & & \\
\hline Pancreas & mRNA, protein $[81,87]$ & Ab $[65,124]$ & Survival, Prognosis $[65,104]$ & Chemoresistance, EMT, Metastasis $[65,104]$ \\
\hline Prostate & protein $[102,111-113]$ & & Prognosis [102] & Growth, Metastasis $[47,102]$ \\
\hline Skin & & T cells [125] & & \\
\hline Thyroid & mRNA $[83,94]$ & & & \\
\hline
\end{tabular}

can therefore speculate that ANX2 is up-regulated even in oral carcinoma, but microenvironment and inflammatory responses related to the anaplastic condition induce down-regulation of ANX2 during cancer progression. Opposite trends reported ANX2 as a suitable prognostic marker in $\mathrm{HCC}$, renal (CRCC), colorectal and gastric carcinomas, where its expression negatively correlates with a favorable clinical outcome [85,93,96,100,101]. In fact, when up-regulated, ANX2 contributes to cancer invasion and metastasis by acting as a co-receptor for plasminogen, tPA and pro-cathepsin B [49]. ANX2-dependent plasmin generation is required for invasion, metastasis and angiogenesis in several cancer types $[47,65,68,114-117]$. For example, it has been demonstrated that in pancreatic cancer (PDAC), tyrosine 23 phosphorylation is necessary for cellsurface localization of ANX2. This translocation is critical for the Transforming Growth Factor beta (TGFbeta)induced, Rho-mediated epithelial-to-mesenchymal transition (EMT) [65]. Moreover, in PDAC, ANX2 overexpression is a predictor of rapid recurrence after surgery in patients who have undergone gemcitabine-adjuvant chemotherapy [104]. In conclusion, we can hypothesize that in tumors where ANX2 is overexpressed, its role as a plasminogen receptor predominates, and is responsible for the metastatic process, while in tumors where ANX2 is down-regulated, plasminogen-independent mechanisms favor the malignant state through anaplastic transformation.

\section{Expression and function of CK8 in cancer}

Several mechanisms have been proposed for the expression of CK8 on the cell surface. In transformed cells, surface expression could be due to insufficient incorporation into intermediate filaments due to over-production of CK8 [64]. Indeed, CK8 is over-expressed both at the mRNA and the protein level in various carcinomas (Table 2) and is present at the cell surface of several human cancers and established tumor cell lines [51,52,64,88,126-129]. By contrast, healthy human tissues do not express CK8 at the cell surface, with the exception of a sporadic and weak CK8 membrane localization in the liver and heart $[127,130]$.

When present on the cancer cell surface, CK8 binds plasminogen and promotes its activation through plasminogen activators. In breast cancer cells it also works as a receptor for uPA [134], suggesting a model in which CK8, in complex with uPA, plasminogen and fibronectin constitutes a signaling platform capable of modulating cell adhesion and growth. Indeed, increased expression of CK8/CK18 has been shown at the invasive front of certain tumors [145]. Of particular note, over-expression of CK8 on the tumor cell surface and in the cytoplasm correlates, both in vitro and in vivo, with increased invasiveness and metastatic properties [144]. In breast and endometrial cancer, a clear correlation exists between CK8 expression and tumor stage [133,144], and CK8 confers drug resistance to chemotherapeutic treatment 
Table 2 Expression, immune response, clinical correlation and function of CK8 in cancer

\begin{tabular}{lllll}
\hline Cancer tissue & Expression & $\begin{array}{l}\text { Immune } \\
\text { response }\end{array}$ & Clinical correlation & Function \\
\hline Breast & protein [52,64,127,131] & Ab [132] & $\begin{array}{l}\text { Prognosis, Survival, Diagnosis } \\
{[131,133]}\end{array}$ & $\begin{array}{l}\text { Chemoresistance, Growth, Metastasis } \\
{[134-136]}\end{array}$ \\
Colon & & Ab [137] & & \\
Gastric & mRNA [128] & Ab [138] & & \\
Head and & protein [51] & Ab [51,139] & & \\
neck & mRNA, protein [52,88] & Ab [140,141] & Prognosis [130] \\
Liver & mRNA, protein & & Survival [126,142] & \\
Lung & {$[126,129]$} & & & Metastasis [143] \\
Skin & & & Prognosis [144] \\
Uterus & & &
\end{tabular}

in breast cancer cell lines $[135,136]$. The effect of CK8 over-expression on survival remains controversial as in non-small cell lung carcinomas (NSCLC), increasing serum levels of CK8 were significantly associated with tumor progression and lower patient survival [126,142], whereas breast cancer patients with low expression of CK8 and high expression of Human Epidermal Growth Factor Receptor 2 (HER2) have a higher risk of recurrence and death within 5 years (Table 2) [131].

\section{Expression and function of ENOA in cancer}

ENOA over-expression is associated with tumor development through a process known as aerobic glycolysis or the Warburg effect [146], which determines an increase in anaerobic glycolysis in hypoxic conditions, a very common feature in most solid tumors, but also in the presence of normal levels of oxygen [147-149]. The ENOA promoter contains a hypoxia responsive element $[150,151]$ that leads to self up-regulation at both the mRNA and protein levels (Table 3) [130,152-173]. However, in a small fraction of NSCLC [174], ENOA expression is down-regulated and, interestingly, is a gene that can be homozygously absent in tumors [175]. In PDAC, ENOA is not only up-regulated but is also subjected to specific post-translational modifications, namely acetylation, methylation and phosphorylation which do not occur in normal tissue $[67,176]$.

Moreover, ENOA is expressed on the surface of hematopoietic cells, such as monocytes, T cells, B cells and neutrophils according to their activation status or pathophysiological conditions [54]. ENOA is localized on the cell surface of PDAC, breast and lung cancers

Table 3 Expression, immune response, clinical correlation and function of ENOA in cancer

\begin{tabular}{|c|c|c|c|c|}
\hline Cancer Tissue & Expression & Immune response & Clinical correlation & Function \\
\hline Brain & mRNA [152] & & & \\
\hline Bone & protein [170] & & Prognosis [170] & \\
\hline Breast & mRNA, protein $[164,167,177]$ & $\mathrm{Ab}[178,179]$ & Prognosis, Survival $[167,178]$ & $\begin{array}{l}\text { Chemoresistance, Metastasis } \\
{[167,177,178]}\end{array}$ \\
\hline Colon & mRNA, protein $[152,158,168]$ & & & \\
\hline Gastric & mRNA, protein $[152,162,169]$ & T cells $[180]$ & & \\
\hline Head and neck & mRNA, protein $[155,166,171]$ & $\mathrm{Ab}[119,120]$ & Prognosis [166] & Metastasis [166] \\
\hline $\begin{array}{l}\text { Hematopoietic } \\
\text { system }\end{array}$ & protein [160] & $\mathrm{Ab}[181]$ & & \\
\hline Liver & mRNA, protein $[130,152,156,165]$ & & Prognosis $[156,165]$ & Growth, Metastasis [156] \\
\hline Lung & $\begin{array}{l}\text { mRNA, protein } \\
{[152,159,172,174,182]}\end{array}$ & Ab [159,172,178,183,184] & $\begin{array}{l}\text { Prognosis, Survival } \\
{[172,174,178]}\end{array}$ & \\
\hline Ovary & mRNA, protein $[152,153]$ & & & \\
\hline Pancreas & mRNA, protein $[152,154,161,163]$ & $\begin{array}{l}\text { Ab and T cells } \\
{[154,185,186]}\end{array}$ & Survival [185] & \\
\hline Prostate & mRNA, protein $[152,187]$ & & & \\
\hline Skin & mRNA [173] & $\mathrm{Ab}[173,188]$ & & \\
\hline
\end{tabular}


$[67,154,172,189]$ (Table 3), while in melanoma and NSCLC it is also secreted by exosomes $[190,191]$. On cell surfaces, ENOA is part of a multi-protein complex, together with uPA receptor (uPAR), integrins and certain cytoskeletal proteins, collectively known as a metastasome, responsible for adhesion, migration and proliferation, as clearly demonstrated in ovarian cancer cells [192]. Moreover, since ENOA interacts with the cytoskeleton in muscle cells, its over-expression is likely to promote migration of tumor cells by providing ATP [29]. Noteworthy, in human follicular thyroid carcinoma cells, retinoic acid causes a decrease in ENOA levels that coincides with their reduced motility [193], while cell surface ENOA is enhanced in breast cancer cells rendered super-invasive following paclitaxel treatment [194].

The prognostic value of ENOA expression has been observed in several tumors (Table 3) [156,165-167,170, $172,174,178,185]$. In breast cancer, enhanced ENOA expression correlates with a greater tumor size, poor nodal status and a shorter disease-free interval. Higher expression of ENOA increases the risk of longer distance relapse when compared to loco-regional relapse in postsurgical 4-Hydroxytamoxifen-treated Estrogen Receptor-positive breast cancer patients. Therefore, down-regulation of ENOA could be a novel pharmacological approach for overcoming 4-Hydroxytamoxifen resistance in breast cancer therapy [167]. In head and neck cancer and NSCLC, ENOA levels increase with cancer progression and negatively correlate with patients' overall- and progression-free survival [166]. In HCC, ENOA expression is up-regulated in poorly differentiated tumors compared to welldifferentiated ones, and its levels positively correlate with tumor size and venous invasion $[156,165]$. Even if ENO1 are not currently used in clinical routine, the altered expression or the induced immune response, as show later, may have a prognostic/diagnostic value, especially in combination with gold-standard markers. For example, in PDAC, the detection of serum antibodies against phosphorylated ENOA, in combination with the commonly used serum marker CA19.9, enhances the ability to discriminate between control and cancer patients [185]. Taken together, these findings determine that ENOA is a good biomarker to monitor tumor progression and to predict clinical outcome.

Plasminogen receptors elicit immune responses in cancer Activation of the immune system is an early event during tumorigenesis, as illustrated by the detection of high titers of autoantibodies in patients with early-stage cancer, and correlates with the progression of malignant transformation $[119,195,196]$. The presence of an immune response to the plasminogen receptors ANX2, CK8 and ENOA has been reported in patients with different types of cancer.
An autoantibody response against ANX2 occurs in the early stages of gingivo-buccal carcinogenesis and in PDAC, ovarian, and lung cancer (Table 1) $[65,119,120,122,123]$. It has been demonstrated that in melanoma, the ANX2 (208-223) peptide induces antigen-specific T cells, which can recognize cancer cells over-expressing the ANX2 molecule. This peptide may therefore be useful in immunotherapy for recruiting CD4+ type 1 helper cells locally active in the tumor environment [125]. Moreover, phase II clinical trial PDAC patients [124] showed an increased anti-ANX2 antibody response after administration of the GM-CSF (granulocyte-macrophage colony-stimulating factor) PDAC-specific vaccine, which positively correlated with prolonged survival [65].

CK8/18 complexes elicit humoral responses in breast, gastric, colon, head and neck and liver carcinomas [51,132,137-141]. In squamous cell carcinoma (SCC), elevated titers of CK8-specific serum antibodies are detectable in early stage patients, while a weaker humoral response has been observed in advanced patients, probably due to immunosuppression by tumor cells. In several adenocarcinomas, patients develop an immune response against tumoral neo-epitopes of CK8 [137], while head and neck and lung cancer patients develop autoantibodies against posttranslationally modified variants of the protein (Table 2) $[139,142]$. The induction of specific antibodies against CK8 can be explained by its ectopic expression on the cancer cell surface that makes CK8 a potential candidate for antibody-based cancer therapy.

A humoral and/or $\mathrm{T}$ cell immune response against ENOA has been observed in patients with breast, head and neck, gastric, lung cancer, chronic myeloid leukemia, melanoma and PDAC (Table 3) [119,120,154,159,172,173, 178-181,183-186,188]. Notably, detection of autoantibodies against ENOA combined with expression of carcinoembryonic antigen (CEA) and CK19 fragment enhances the sensitivity for differential diagnosis of NSCLC [184]. High levels of antibodies to phosphorylated ENOA were found in PDAC, and their combination with the serological marker CA19.9 discriminates patients from controls [185]. The presence of the humoral response to phosphorylated ENOA also correlates with a longer progression-free survival upon gemcitabine treatment and overall survival [185] and notably, with the presence of a specific $\mathrm{T}$ cell response [154,180,186,197]. Conversely, a marked decrease in basal levels of ENOA-autoantibodies is a common event in late lung and breast cancers, proposing ENOAautoantibodies as a prognostic marker to monitor disease progression in these patients [178].

\section{Plasminogen receptors as therapeutic targets in cancer}

Despite heterogeneous numbers of plasminogen receptors existing in eukaryotic cells, only ENOA, CK8 and ANX2 have a recognized role in human cancer 
progression by promoting plasmin-dependent tumor invasion. ANX2 also behaves as a tPA receptor, whilst ENOA and CK8 do not directly bind plasminogen activators, but most likely form a multi-protein complex with UPAR and integrins [64,67]. Nevertheless, the contribution of these three receptors to cancer development is not only linked to their plasminogen-binding capacity. Indeed ANX2, ENOA and CK8 all interact with the actin cytoskeleton and such an association could promote the migration of tumor cells independently from plasminogen-binding [29]. These three receptors are present on the surface of the majority of human neoplasms, and in some cases, such as breast and colon, they are expressed altogether. All of these receptors elicit an antibody immune response in cancer patients that can be potentially boosted for therapeutic purposes. Regarding the potential risk of inducing an autoimmune reaction, CK8 would probably be the best candidate as it is aberrantly expressed only on the tumor cell surface. However, even the ANX2 and ENOA are frequently over-expressed by tumor cells and exposed on the cell surface. This strengthens the hypothesis for utilizing them as potential targets of therapeutic monoclonal antibodies. Notably, data obtained in animal models show a therapeutic effect of anti-ANX2 monoclonal antibody $(\mathrm{mAb})$ treatment in breast, pancreatic and lung cancer by inhibiting tumor growth, suppressing metastases and prolonging survival (Table 1) [65,114,117]. Thus, blocking plasminogen receptors is a promising strategy to counteract metastasis development.

A recent paper has shown that a DNA-based vaccination against human ENOA, followed by electroporation, was able to significantly prolong the median of life expectancy of mice that spontaneously develop PDAC [186]. Indeed, the ENOA DNA vaccine induced both a humoral and cellular response. Autoantibodies against ENOA were able to bind the cell surface of PDAC murine cells and mediate their killing by complement-dependent cytotoxicity. This "immunogenic" death might be responsible for the greater influx of CD3 into tumor and for their activation toward Th1/Th17 phenotype. Cytokines produced by these Th populations strongly supported the "effecto" switching of anti-ENOA autoantibodies [186]. Moreover, the ENOA-DNA vaccine significantly decreased suppressor cells such as myeloid-derived suppressor cells and regulatory $\mathrm{T}$ cells $[186]$.

\section{Conclusions}

Overall, with very few exceptions, all three plasminogen receptors reported here display performant diagnostic and prognostic values. Since one single receptor type is not expected to account for the entire plasminogen binding on tumor cells, a combined therapy targeting all these molecules would be desirable. Nevertheless, further studies are necessary in order to better understand the involvement of these three receptors in cancer progression, so that more effective strategies for cancer treatment may be developed.

\section{Abbreviations}

aa: amino acid; ANX2: Annexin 2; CA19.9: Carbohydrate antigen 19.9; CEA: Carcino-embryonic antigen; CK8: Cytokeratin 8; CK18: Cytokeratin 18; CK19: Cytokeratin 19; CRCC: Chromophobe renal cell carcinoma; EMT: Epithelial mesenchymal transition; EGF: Epidermal growth factor; ENOA: Alpha-enolase; FGF: Fibroblast growth factor; GM-CSF: Granulocyte-macrophage colonystimulating factor; GPC3: Glypican 3; GS: Glutamine synthetase; HCC: Hepatocellular carcinoma; HER2: Human epidermal growth factor receptor 2; HSP70: Heat shock protein 70; kDa: Kilo-Dalton; Lys: Lysine; mAb: monoclonal antibody; MMP3: Matrix metalloproteinases 3; NSCLC: Non-small cell lung cancer; PDAC: Pancreatic ductal adenocarcinoma; PEP: Phosphoenolpyruvate; PGA: 2-phospho-D-glycerate; PKC: Protein kinase C; SCC: Squamous cell carcinoma; Ser: Serine; TGFbeta: Transforming Growth Factor beta; Th: T helper cell; tPA: tissue-type activator; Tyr: Tyrosine; UPA: urokinase-type activator; UPAR: urokinase-type activator receptor.

\section{Competing interests}

The authors declare that they have no competing interests.

\section{Authors' contributions}

$P C$ and MP equally contributed to writing the first draft. $M C$ and $P C$ refined the draft version of the manuscript. FN supervised the other contributors and critically revised the manuscript. All authors read and approved the final manuscript.

\section{Acknowledgements}

This work was supported in part by grants from: the European Community, Seventh Framework Program European Pancreatic Cancer-TumorMicroenvironment Network (EPC-TM-Net, no. 256974); Associazione Italiana Ricerca sul Cancro (AIRC) $5 \times 1000$ (no. 12182) and IG (no. 5548 and 11643); Ministero della Salute: Progetto Integrato Oncologia; Regione Piemonte: Ricerca Industriale e Sviluppo Precompetitivo (BIOPRO and ONCOPROT), Ricerca Industriale "Converging Technologies" (BIOTHER), Progetti strategici su tematiche di interesse regionale o sovra regionale (IMMONC), Ricerca Sanitaria Finalizzata, Ricerca Sanitaria Applicata; Ministero dell'Istruzione e della Ricerca (MIUR), Progetti di Rilevante Interesse Nazionale (PRIN 2009); Fondazione Internazionale Ricerca Medicina Sperimentale (FIRMS); University of Turin, Progetti di Ateneo 2011 (RETHE ORTO11RKTW). MC is a recipient of a fellowship from the Fondazione Italiana Ricerca sul Cancro (FIRC). We thank Dr. Radhika Srinivasan for critically reviewing the manuscript.

Received: 28 March 2013 Accepted: 28 March 2013

Published: 17 April 2013

\section{References}

1. Kwaan HC, McMahon B: The role of plasminogen-plasmin system in cancer. Cancer Treat Res 2009, 148:43-66.

2. Andreasen PA, Egelund $\mathrm{R}$, Petersen $\mathrm{HH}$ : The plasminogen activation system in tumor growth, invasion, and metastasis. Cell Mol Life Sci 2000, 57:25-40.

3. Dano K, Behrendt N, Hoyer-Hansen G, Johnsen M, Lund LR, Ploug M, Romer J: Plasminogen activation and cancer. Thromb Haemost 2005, 93:676-681.

4. Plow EF, Herren T, Redlitz A, Miles LA, Hoover-Plow JL: The cell biology of the plasminogen system. FASEB J 1995, 9:939-945.

5. McMahon B, Kwaan HC: The plasminogen activator system and cancer. Pathophysiol Haemost Thromb 2008, 36:184-194.

6. Shin SJ, Kim KO, Kim MK, Lee KH, Hyun MS, Kim KJ, Choi JH, Song HS: Expression of E-cadherin and UPA and their association with the prognosis of pancreatic cancer. Jpn J Clin Oncol 2005, 35:342-348.

7. Xue A, Scarlett CJ, Jackson CJ, Allen BJ, Smith RC: Prognostic significance of growth factors and the urokinase-type plasminogen activator system in pancreatic ductal adenocarcinoma. Pancreas 2008, 36:160-167.

8. Tang $L$, Han $X$ : The urokinase plasminogen activator system in breast cancer invasion and metastasis. Biomed Pharmacother 2013, 67:179-182. 
9. Zhang W, Ling D, Tan J, Zhang J, Li L: Expression of urokinase plasminogen activator and plasminogen activator inhibitor type-1 in ovarian cancer and its clinical significance. Oncol Rep 2013, 29:637-645.

10. Markl B, Renk I, Oruzio DV, Jahnig H, Schenkirsch G, Scholer C, Ehret W, Arnholdt HM, Anthuber M, Spatz H: Tumour budding, uPA and PAl-1 are associated with aggressive behaviour in colon cancer. J Surg Oncol 2010, 102:235-241.

11. Berger DH: Plasmin/plasminogen system in colorectal cancer. World J Surg 2002, 26:767-771.

12. Derechin M: Purification of human plasminogen. Biochem J 1962, 82:241-247.

13. Petersen TE, Martzen MR, Ichinose A, Davie EW: Characterization of the gene for human plasminogen, a key proenzyme in the fibrinolytic system. J Biol Chem 1990, 265:6104-6111.

14. Hayes ML, Castellino FJ: Carbohydrate of the human plasminogen variants. I. Carbohydrate composition, glycopeptide isolation, and characterization. J Biol Chem 1979, 254:8768-8771.

15. Hayes ML, Castellino FJ: Carbohydrate of the human plasminogen variants. III. Structure of the O-glycosidically linked oligosaccharide unit J Biol Chem 1979, 254:8777-8780.

16. Vassalli JD, Sappino AP, Belin D: The plasminogen activator/plasmin system. J Clin Invest 1991, 88:1067-1072.

17. Castellino FJ, Ploplis VA: Structure and function of the plasminogen/ plasmin system. Thromb Haemost 2005, 93:647-654.

18. Paciucci $R$, Tora M, Diaz VM, Real FX: The plasminogen activator system in pancreas cancer: role of t-PA in the invasive potential in vitro. Oncogene 1998, 16:625-633.

19. Lijnen HR, Van Hoef B, Lupu F, Moons L, Carmeliet P, Collen D: Function of the plasminogen/plasmin and matrix metalloproteinase systems after vascular injury in mice with targeted inactivation of fibrinolytic system genes. Arterioscler Thromb Vasc Biol 1998, 18:1035-1045.

20. Plow EF, Felez J, Miles LA: Cellular regulation of fibrinolysis. Thromb Haemost 1991, 66:32-36.

21. Sato H, Takino T, Okada Y, Cao J, Shinagawa A, Yamamoto E, Seiki M: A matrix metalloproteinase expressed on the surface of invasive tumour cells. Nature 1994, 370:61-65

22. Vassalli JD, Pepper MS: Tumour biology. Membrane proteases in focus. Nature 1994, 370:14-15.

23. Miles LA, Dahlberg CM, Plescia J, Felez J, Kato K, Plow EF: Role of cell-surface lysines in plasminogen binding to cells: identification of alpha-enolase as a candidate plasminogen receptor. Biochemistry 1991, 30:1682-1691.

24. Miles LA, Hawley SB, Baik N, Andronicos NM, Castellino FJ, Parmer RJ: Plasminogen receptors: the sine qua non of cell surface plasminogen activation. Front Biosci 2005, 10:1754-1762.

25. Plow EF, Freaney DE, Plescia J, Miles LA: The plasminogen system and cell surfaces: evidence for plasminogen and urokinase receptors on the same cell type. J Cell Biol 1986, 103:2411-2420.

26. Lopez-Alemany R, Longstaff C, Hawley S, Mirshahi M, Fabregas P, Jardi M, Merton E, Miles LA, Felez J: Inhibition of cell surface mediated plasminogen activation by a monoclonal antibody against alpha-Enolase. Am J Hematol 2003, 72:234-242.

27. Dano K, Andreasen PA, Grondahl-Hansen J, Kristensen P, Nielsen LS, Skriver L: Plasminogen activators, tissue degradation, and cancer. Adv Cancer Res 1985, 44:139-266

28. Felez J: Plasminogen binding to cell surface. Fibrinolysis Proteolysis 1998 12:183-189.

29. Liu KJ, Shih NY: The role of Enolase in tissue invasion and metastasis of pathogens and tumor cells. J Cancer Mol 2007, 3:45-48.

30. Borza DB, Morgan WT: Acceleration of plasminogen activation by tissue plasminogen activator on surface-bound histidine-proline-rich glycoprotein. J Biol Chem 1997, 272:5718-5726.

31. Das R, Burke T, Plow EF: Histone $\mathrm{H} 2 \mathrm{~B}$ as a functionally important plasminogen receptor on macrophages. Blood 2007, 110:3763-3772.

32. Dudani AK, Cummings C, Hashemi S, Ganz PR: Isolation of a novel 45 kDa plasminogen receptor from human endothelial cells. Thromb Res 1993, 69:185-196.

33. Dudani AK, Ganz PR: Endothelial cell surface actin serves as a binding site for plasminogen, tissue plasminogen activator and lipoprotein(a). Br J Haematol 1996, 95:168-178.

34. Gonzalez-Gronow M, Kaczowka S, Gawdi G, Pizzo SV: Dipeptidyl peptidase IV (DPP IV/CD26) is a cell-surface plasminogen receptor. Front Biosci 2008 $13: 1610-1618$
35. Havre PA, Abe M, Urasaki Y, Ohnuma K, Morimoto C, Dang NH: The role of CD26/dipeptidyl peptidase IV in cancer. Front Biosci 2008, 13:1634-1645.

36. Herren T, Burke TA, Das R, Plow EF: Identification of histone $\mathrm{H} 2 \mathrm{~B}$ as a regulated plasminogen receptor. Biochemistry 2006, 45:9463-9474.

37. Kanalas JJ, Makker SP: Identification of the rat Heymann nephritis autoantigen (GP330) as a receptor site for plasminogen. J Biol Chem 1991, 266:10825-10829.

38. Lighvani S, Baik N, Diggs JE, Khaldoyanidi S, Parmer RJ, Miles LA: Regulation of macrophage migration by a novel plasminogen receptor Plg-R KT. Blood 2011, 118:5622-5630.

39. Phipps KD, Surette AP, O'Connell PA, Waisman DM: Plasminogen receptor $\mathrm{S} 100 \mathrm{~A} 10$ is essential for the migration of tumor-promoting macrophages into tumor sites. Cancer Res 2011, 71:6676-6683.

40. Redlitz A, Fowler BJ, Plow EF, Miles LA: The role of an enolase-related molecule in plasminogen binding to cells. Eur J Biochem 1995, 227:407-415.

41. Strickland DK: A new plasminogen receptor. Blood 2010, 115:1315-1316.

42. Winram SB, Lottenberg R: The plasmin-binding protein PIr of group A streptococci is identified as glyceraldehyde-3-phosphate dehydrogenase. Microbiology 1996, 142(Pt 8):2311-2320.

43. Andronicos NM, Chen El, Baik N, Bai H, Parmer CM, Kiosses WB, Kamps MP, Yates JR 3rd, Parmer RJ, Miles LA: Proteomics-based discovery of a novel, structurally unique, and developmentally regulated plasminogen receptor, Plg-RKT, a major regulator of cell surface plasminogen activation. Blood 2010, 115:1319-1330.

44. Kang HJ, Jung SK, Kim SJ, Chung SJ: Structure of human alpha-enolase (hENO1), a multifunctional glycolytic enzyme. Acta Crystallogr D Biol Crystallogr 2008, 64:651-657.

45. Kang HM, Choi KS, Kassam G, Fitzpatrick SL, Kwon M, Waisman DM: Role of annexin II tetramer in plasminogen activation. Trends Cardiovasc Med 1999, 9:92-102.

46. Liemann S, Lewit-Bentley A: Annexins: a novel family of calcium- and membrane-binding proteins in search of a function. Structure 1995, 3:233-237.

47. Shiozawa Y, Havens AM, Jung Y, Ziegler AM, Pedersen EA, Wang J, Lu G, Roodman GD, Loberg RD, Pienta KJ, Taichman RS: Annexin II/annexin II receptor axis regulates adhesion, migration, homing, and growth of prostate cancer. J Cell Biochem 2008, 105:370-380.

48. Waisman DM: Annexin II tetramer: structure and function. Mol Cell Biochem 1995, 149-150:301-322.

49. Gerke V, Moss SE: Annexins: from structure to function. Physiol Rev 2002, 82:331-371.

50. Moll R, Divo M, Langbein L: The human keratins: biology and pathology. Histochem Cell Biol 2008, 129:705-733.

51. Gires O, Andratschke M, Schmitt B, Mack B, Schaffrik M: Cytokeratin 8 associates with the external leaflet of plasma membranes in tumour cells. Biochem Biophys Res Commun 2005, 328:1154-1162.

52. Hembrough TA, Li L, Gonias SL: Cell-surface cytokeratin 8 is the major plasminogen receptor on breast cancer cells and is required for the accelerated activation of cell-associated plasminogen by tissue-type plasminogen activator. J Biol Chem 1996, 271:25684-25691

53. Kralovich KR, Li L, Hembrough TA, Webb DJ, Karns LR, Gonias SL: Characterization of the binding sites for plasminogen and tissue-type plasminogen activator in cytokeratin 8 and cytokeratin 18. J Protein Chem 1998, 17:845-854

54. Pancholi V: Multifunctional alpha-enolase: its role in diseases. Cell Mol Life Sci 2001, 58:902-920.

55. Lohman K, Meyerhof O: Über die enzymatische Umwandlung von Phosphoglyzerinsäure in Brenztraubensäure und Phosphorsäure (Enzymatic transformation of phosphoglyceric acid into pyruvic and phosphoric acid). Biochem Z 1934, 273:60-72.

56. Giallongo A, Oliva D, Cali L, Barba G, Barbieri G, Feo S: Structure of the human gene for alpha-enolase. Eur J Biochem 1990, 190:567-573.

57. Marangos PJ, Zis AP, Clark RL, Goodwin FK: Neuronal, non-neuronal and hybrid forms of enolase in brain: structural, immunological and functional comparisons. Brain Res 1978, 150:117-133.

58. Kato K, Asai R, Shimizu A, Suzuki F, Ariyoshi Y: Immunoassay of three enolase isozymes in human serum and in blood cells. Clin Chim Acta 1983, 127:353-363.

59. Royds JA, Parsons MA, Taylor CB, Timperley WR: Enolase isoenzyme distribution in the human brain and its tumours. J Pathol 1982, 137:37-49. 
60. Asch HL, Mayhew E, Lazo RO, Asch BB: Lipids noncovalently associated with keratins and other cytoskeletal proteins of mouse mammary epithelial cells in primary culture. Biochim Biophys Acta 1990, 1034:303-308.

61. Vidrich A, Gilmartin ME, Mitchell J, Freedberg IM: Postsynthetic modifications of epithelial keratins. Ann N Y Acad Sci 1985, 455:354-370.

62. Chan R, Rossitto PV, Edwards BF, Cardiff RD: Presence of proteolytically processed keratins in the culture medium of MCF-7 cells. Cancer Res $1986,46: 6353-6359$

63. Chou CF, Riopel CL, Rott LS, Omary MB: A significant soluble keratin fraction in 'simple' epithelial cells. Lack of an apparent phosphorylation and glycosylation role in keratin solubility. J Cell Sci 1993, 105(Pt 2):433-444.

64. Hembrough TA, Kralovich KR, Li L, Gonias SL: Cytokeratin 8 released by breast carcinoma cells in vitro binds plasminogen and tissue-type plasminogen activator and promotes plasminogen activation. Biochem 1996, 317(Pt 3):763-769.

65. Zheng L, Foley K, Huang L, Leubner A, Mo G, Olino K, Edil BH, Mizuma M, Sharma R, Le DT, et al: Tyrosine 23 phosphorylation-dependent cellsurface localization of annexin A2 is required for invasion and metastases of pancreatic cancer. PLoS One 2011, 6:e19390.

66. Cooper JA, Esch FS, Taylor SS, Hunter T: Phosphorylation sites in enolase and lactate dehydrogenase utilized by tyrosine protein kinases in vivo and in vitro. J Biol Chem 1984, 259:7835-7841.

67. Capello M, Ferri-Borgogno S, Cappello P, Novelli F: alpha-Enolase: a promising therapeutic and diagnostic tumor target. FEBS J 2011, 278:1064-1074.

68. Bao H, Jiang M, Zhu M, Sheng F, Ruan J, Ruan C: Overexpression of Annexin II affects the proliferation, apoptosis, invasion and production of proangiogenic factors in multiple myeloma. Int J Hematol 2009, 90:177-185.

69. Chiang Y, Rizzino A, Sibenaller ZA, Wold MS, Vishwanatha JK: Specific down-regulation of annexin II expression in human cells interferes with cell proliferation. Mol Cell Biochem 1999, 199:139-147.

70. Creutz CE: The annexins and exocytosis. Science 1992, 258:924-931.

71. Hajjar KA, Krishnan S: Annexin II: a mediator of the plasmin/plasminogen activator system. Trends Cardiovasc Med 1999, 9:128-138.

72. Hajjar KA, Menell JS: Annexin II: a novel mediator of cell surface plasmin generation. Ann N Y Acad Sci 1997, 811:337-349.

73. Ling $Q$, Jacovina AT, Deora A, Febbraio M, Simantov R, Silverstein RL, Hempstead B, Mark WH, Hajjar KA: Annexin II regulates fibrin homeostasis and neoangiogenesis in vivo. J Clin Invest 2004, 113:38-48.

74. Gould KL, Woodgett JR, Isacke CM, Hunter T: The protein-tyrosine kinase substrate p36 is also a substrate for protein kinase $C$ in vitro and in vivo. Mol Cell Biol 1986, 6:2738-2744

75. Hayes MJ, Moss SE: Annexin 2 has a dual role as regulator and effector of v-Src in cell transformation. J Biol Chem 2009, 284:10202-10210.

76. Hubaishy I, Jones PG, Bjorge J, Bellagamba C, Fitzpatrick S, Fujita DJ, Waisman DM: Modulation of annexin II tetramer by tyrosine phosphorylation. Biochem 1995, 34:14527-14534.

77. Biener $Y$, Feinstein R, Mayak M, Kaburagi Y, Kadowaki T, Zick Y: Annexin II is a novel player in insulin signal transduction. Possible association between annexin II phosphorylation and insulin receptor internalization. J Biol Chem 1996, 271:29489-29496.

78. Jiang Y, Chan JL, Zong CS, Wang LH: Effect of tyrosine mutations on the kinase activity and transforming potential of an oncogenic human insulin-like growth factor I receptor. J Biol Chem 1996, 271:160-167.

79. Brambilla R, Zippel R, Sturani E, Morello L, Peres A, Alberghina L: Characterization of the tyrosine phosphorylation of calpactin I (annexin II) induced by platelet-derived growth factor. Biochem J 1991, 278(Pt 2):447-452.

80. Zhao WQ, Chen GH, Chen H, Pascale A, Ravindranath L, Quon MJ, Alkon DL: Secretion of Annexin II via activation of insulin receptor and insulin-like growth factor receptor. J Biol Chem 2003, 278:4205-4215.

81. Chen R, Brentnall TA, Pan S, Cooke K, Moyes KW, Lane Z, Crispin DA, Goodlett DR, Aebersold R, Bronner MP: Quantitative proteomics analysis reveals that proteins differentially expressed in chronic pancreatitis are also frequently involved in pancreatic cancer. Mol Cell Proteomics 2007 6:1331-1342.

82. Cole SP, Pinkoski MJ, Bhardwaj G, Deeley RG: Elevated expression of annexin II (lipocortin II, p36) in a multidrug resistant small cell lung cancer cell line. Br J Cancer 1992, 65:498-502.

83. Delys $L$, Detours V, Franc B, Thomas G, Bogdanova T, Tronko M, Libert F, Dumont JE, Maenhaut C: Gene expression and the biological phenotype of papillary thyroid carcinomas. Oncogene 2007, 26:7894-7903.
84. Domoto T, Miyama Y, Suzuki H, Teratani T, Arai K, Sugiyama T, Takayama T, Mugiya S, Ozono S, Nozawa R: Evaluation of S100A10, annexin II and BFABP expression as markers for renal cell carcinoma. Cancer Sci 2007, 98:77-82.

85. Emoto K, Sawada H, Yamada Y, Fujimoto H, Takahama Y, Ueno M, Takayama T, Uchida H, Kamada K, Naito A, et al: Annexin II overexpression is correlated with poor prognosis in human gastric carcinoma. Anticancer Res 2001, 21:1339-1345.

86. Emoto K, Yamada Y, Sawada H, Fujimoto H, Ueno M, Takayama T, Kamada K, Naito A, Hirao S, Nakajima Y: Annexin II overexpression correlates with stromal tenascin-C overexpression: a prognostic marker in colorectal carcinoma. Cancer 2001, 92:1419-1426.

87. Esposito I, Penzel R, Chaib-Harrireche M, Barcena U, Bergmann F, Riedl S, Kayed $H$, Giese N, Kleeff J, Friess H, Schirmacher P: Tenascin C and annexin II expression in the process of pancreatic carcinogenesis. J Pathol 2006, 208:673-685.

88. Guedj N, Zhan Q, Perigny M, Rautou PE, Degos F, Belghiti J, Farges O, Bedossa $\mathrm{P}$, Paradis V: Comparative protein expression profiles of hilar and peripheral hepatic cholangiocarcinomas. J Hepatol 2009, 51:93-101.

89. Guzman Aranguez A, Olmo N, Turnay J, Lecona E, Perez Ramos P, Lopez De Silanes I, Lizarbe MA: Differentiation of human colon adenocarcinoma cells alters the expression and intracellular localization of annexins A1, A2, and A5. J Cell Biochem 2005, 94:178-193.

90. Ji NY, Park MY, Kang YH, Lee Cl, Kim DG, Yeom Yl, Jang YJ, Myung PK, Kim $J W$, Lee HG, et al: Evaluation of annexin II as a potential serum marker for hepatocellular carcinoma using a developed sandwich ELISA method. Int J Mol Med 2009, 24:765-771.

91. Liu Y, Wang Z, Jiang M, Dai L, Zhang W, Wu D, Ruan C: The expression of annexin II and its role in the fibrinolytic activity in acute promyelocytic leukemia. Leuk Res 2011, 35:879-884.

92. Liu Y, Zhu X, Zhu J, Liao S, Tang Q, Liu K, Guan X, Zhang J, Feng Z: Identification of differential expression of genes in hepatocellular carcinoma by suppression subtractive hybridization combined cDNA microarray. Oncol Rep 2007, 18:943-951.

93. Mohammad HS, Kurokohchi K, Yoneyama H, Tokuda M, Morishita A, Jian G, Shi L, Murota M, Tani J, Kato K, et al: Annexin A2 expression and phosphorylation are up-regulated in hepatocellular carcinoma. Int J Oncol 2008, 33:1157-1163.

94. Musholt TJ, Hanack J, Brehm C, von Wasielewski R, Musholt PB: Searching for non-RET molecular alterations in medullary thyroid carcinoma: expression analysis by mRNA differential display. World J Surg 2005, 29:472-482.

95. Olwill SA, McGlynn H, Gilmore WS, Alexander HD: Annexin II cell surface and mRNA expression in human acute myeloid leukaemia cell lines. Thromb Res 2005, 115:109-114.

96. Pei H, Zhu H, Zeng S, Li Y, Yang H, Shen L, Chen J, Zeng L, Fan J, Li X, et al: Proteome analysis and tissue microarray for profiling protein markers associated with lymph node metastasis in colorectal cancer. J Proteome Res 2007, 6:2495-2501.

97. Reeves SA, Chavez-Kappel C, Davis R, Rosenblum M, Israel MA: Developmental regulation of annexin II (Lipocortin 2) in human brain and expression in high grade glioma. Cancer Res 1992, 52:6871-6876.

98. Roseman BJ, Bollen A, Hsu J, Lamborn K, Israel MA: Annexin II marks astrocytic brain tumors of high histologic grade. Oncol Res 1994, 6:561-567.

99. Zhang J, Guo B, Zhang Y, Cao J, Chen T: Silencing of the annexin II gene down-regulates the levels of S100A10, c-Myc, and plasmin and inhibits breast cancer cell proliferation and invasion. Saudi Med J 2010, 31:374-381.

100. Zhong LP, Wei KJ, Yang X, Zhang L, Zhou XJ, Pan HY, Li J, Chen WT, Zhang $Z Y$ : Increased expression of Annexin A2 in oral squamous cell carcinoma. Arch Oral Biol 2009, 54:17-25.

101. Zimmermann U, Woenckhaus C, Pietschmann S, Junker H, Maile S, Schultz K, Protzel C, Giebel J: Expression of annexin II in conventional renal cell carcinoma is correlated with Fuhrman grade and clinical outcome. Virchows Arch 2004, 445:368-374.

102. Inokuchi J, Narula N, Yee DS, Skarecky DW, Lau A, Ornstein DK, Tyson DR: Annexin A2 positively contributes to the malignant phenotype and secretion of IL-6 in DU145 prostate cancer cells. Int J Cancer 2009, 124:68-74.

103. Longerich T, Haller MT, Mogler C, Aulmann S, Lohmann V, Schirmacher $P$, Brand K: Annexin A2 as a differential diagnostic marker of hepatocellular tumors. Pathol Res Pract 2011, 207:8-14. 
104. Takano S, Togawa A, Yoshitomi H, Shida T, Kimura F, Shimizu H, Yoshidome $\mathrm{H}$, Ohtsuka M, Kato A, Tomonaga T, et al: Annexin II overexpression predicts rapid recurrence after surgery in pancreatic cancer patients undergoing gemcitabine-adjuvant chemotherapy. Ann Surg Oncol 2008, 15:3157-3168

105. Pena-Alonso E, Rodrigo JP, Parra IC, Pedrero JM, Meana MV, Nieto CS, Fresno MF, Morgan RO, Fernandez MP: Annexin A2 localizes to the basal epithelial layer and is down-regulated in dysplasia and head and neck squamous cell carcinoma. Cancer Lett 2008, 263:89-98.

106. Qi YJ, He QY, Ma YF, Du YW, Liu GC, Li YJ, Tsao GS, Ngai SM, Chiu JF: Proteomic identification of malignant transformation-related proteins in esophageal squamous cell carcinoma. J Cell Biochem 2008, 104:1625-1635.

107. Rodrigo JP, Lequerica-Fernandez P, Rosado P, Allonca E, Garcia-Pedrero JM, de Vicente JC: Clinical significance of annexin A2 downregulation in oral squamous cell carcinoma. Head Neck 2011, 33:1708-1714.

108. Zhang $X$, Zhi HY, Zhang J, Wang XQ, Zhou CN, Wu M, Sun YT, Liu ZH: Expression of annexin II in human esophageal squamous cell carcinoma. Zhonghua Zhong Liu Za Zhi 2003, 25:353-355.

109. Zhi H, Zhang J, Hu G, Lu J, Wang X, Zhou C, Wu M, Liu Z: The deregulation of arachidonic acid metabolism-related genes in human esophageal squamous cell carcinoma. Int J Cancer 2003, 106:327-333.

110. Gillette JM, Chan DC, Nielsen-Preiss SM: Annexin 2 expression is reduced in human osteosarcoma metastases. J Cell Biochem 2004, 92:820-832.

111. Chetcuti A, Margan SH, Russell P, Mann S, Millar DS, Clark SJ, Rogers J, Handelsman DJ, Dong Q: Loss of annexin II heavy and light chains in prostate cancer and its precursors. Cancer Res 2001, 61:6331-6334.

112. Liu JW, Shen JJ, Tanzillo-Swarts A, Bhatia B, Maldonado CM, Person MD, Lau SS, Tang DG: Annexin II expression is reduced or lost in prostate cancer cells and its re-expression inhibits prostate cancer cell migration. Oncogene 2003, 22:1475-1485.

113. Yee DS, Narula N, Ramzy I, Boker J, Ahlering TE, Skarecky DW, Ornstein DK: Reduced annexin II protein expression in high-grade prostatic intraepithelial neoplasia and prostate cancer. Arch Pathol Lab Med 2007, 131:902-908.

114. Sharma M, Blackman MR, Sharma MC: Antibody-directed neutralization of annexin II (ANX II) inhibits neoangiogenesis and human breast tumor growth in a xenograft model. Exp Mol Pathol 2012, 92:175-184.

115. Sharma M, Ownbey RT, Sharma MC: Breast cancer cell surface annexin II induces cell migration and neoangiogenesis via tPA dependent plasmin generation. Exp Mol Pathol 2010, 88:278-286.

116. Sharma MR, Koltowski L, Ownbey RT, Tuszynski GP, Sharma MC: Angiogenesis-associated protein annexin II in breast cancer: selective expression in invasive breast cancer and contribution to tumor invasion and progression. Exp Mol Pathol 2006, 81:146-156.

117. Sharma MR, Rothman V, Tuszynski GP, Sharma MC: Antibody-directed targeting of angiostatin's receptor annexin II inhibits Lewis Lung Carcinoma tumor growth via blocking of plasminogen activation: possible biochemical mechanism of angiostatin's action. Exp Mol Pathol 2006, 81:136-145.

118. Zhang F, Zhang L, Zhang B, Wei X, Yang Y, Qi RZ, Ying G, Zhang N, Niu R: Anxa2 plays a critical role in enhanced invasiveness of the multidrug resistant human breast cancer cells. J Proteome Res 2009, 8:5041-5047.

119. Shukla S, Govekar RB, Sirdeshmukh R, Sundaram CS, D'Cruz AK, Pathak KA, Kane SV, Zingde SM: Tumor antigens eliciting autoantibody response in cancer of gingivo-buccal complex. Proteomics Clin Appl 2007, 1:1592-1604.

120. Shukla S, Pranay A, D'Cruz AK, Chaturvedi P, Kane SV, Zingde SM: Immunoproteomics reveals that cancer of the tongue and the gingivobuccal complex exhibit differential autoantibody response. Cancer Biomark 2009, 5:127-135.

121. Ohno Y, Izumi M, Kawamura T, Nishimura T, Mukai K, Tachibana M: Annexin II represents metastatic potential in clear-cell renal cell carcinoma. Br J Cancer 2009, 101:287-294.

122. Brichory FM, Misek DE, Yim AM, Krause MC, Giordano TJ, Beer DG, Hanash $\mathrm{SM}$ : An immune response manifested by the common occurrence of annexins I and II autoantibodies and high circulating levels of IL-6 in lung cancer. Proc Natl Acad Sci USA 2001, 98:9824-9829.

123. Barua A, Edassery SL, Bitterman P, Abramowicz JS, Dirks AL, Bahr JM, Hales DB, Bradaric MJ, Luborsky JL: Prevalence of antitumor antibodies in laying hen model of human ovarian cancer. Int J Gynecol Cancer 2009, 19:500-507.

124. Lutz E, Yeo CJ, Lillemoe KD, Biedrzycki B, Kobrin B, Herman J, Sugar E, Piantadosi S, Cameron JL, Solt S, et al: A lethally irradiated allogeneic granulocyte-macrophage colony stimulating factor-secreting tumor vaccine for pancreatic adenocarcinoma. A Phase II trial of safety, efficacy, and immune activation. Ann Surg 2011, 253:328-335.

125. Heinzel S, Rea D, Offringa R, Pawelec $G$ : The self peptide annexin II (208-223) presented by dendritic cells sensitizes autologous CD4+ T lymphocytes to recognize melanoma cells. Cancer Immunol Immunother 2001, 49:671-678.

126. Fukunaga Y, Bandoh S, Fujita J, Yang Y, Ueda Y, Hojo S, Dohmoto K, Tojo Y, Takahara J, Ishida T: Expression of cytokeratin 8 in lung cancer cell lines and measurement of serum cytokeratin 8 in lung cancer patients. Lung Cancer 2002, 38:31-38.

127. Imai S, Nagano K, Yoshida Y, Okamura T, Yamashita T, Abe Y, Yoshikawa T, Yoshioka Y, Kamada H, Mukai Y, et al: Development of an antibody proteomics system using a phage antibody library for efficient screening of biomarker proteins. Biomaterials 2011, 32:162-169.

128. Kim TM, Jeong HJ, Seo MY, Kim SC, Cho G, Park CH, Kim TS, Park KH, Chung HC, Rha SY: Determination of genes related to gastrointestinal tract origin cancer cells using a cDNA microarray. Clin Cancer Res 2005, 11:79-86.

129. Wikman H, Kettunen E, Seppanen JK, Karjalainen A, Hollmen J, Anttila S, Knuutila S: Identification of differentially expressed genes in pulmonary adenocarcinoma by using cDNA array. Oncogene 2002, 21:5804-5813.

130. Teramoto R, Minagawa H, Honda M, Miyazaki K, Tabuse Y, Kamijo K, Ueda T, Kaneko S: Protein expression profile characteristic to hepatocellular carcinoma revealed by 2D-DIGE with supervised learning. Biochim Biophys Acta 2008, 1784:764-772.

131. Livasy CA, Karaca G, Nanda R, Tretiakova MS, Olopade OI, Moore DT, Perou CM: Phenotypic evaluation of the basal-like subtype of invasive breast carcinoma. Mod Pathol 2006, 19:264-271.

132. Hamrita B, Chahed K, Kabbage M, Guillier CL, Trimeche M, Chaieb A, Chouchane $\mathrm{L}$ : Identification of tumor antigens that elicit a humoral immune response in breast cancer patients' sera by serological proteome analysis (SERPA). Clin Chim Acta 2008, 393:95-102.

133. Bonin S, Brunetti D, Benedetti E, Dotti I, Gorji N, Stanta G: Molecular characterisation of breast cancer patients at high and low recurrence risk. Virchows Arch 2008, 452:241-250.

134. Obermajer N, Doljak B, Kos J: Cytokeratin 8 ectoplasmic domain binds urokinase-type plasminogen activator to breast tumor cells and modulates their adhesion, growth and invasiveness. Mol Cancer 2009, 8:88.

135. Liu F, Chen Z, Wang J, Shao X, Cui Z, Yang C, Zhu Z, Xiong D: Overexpression of cell surface cytokeratin 8 in multidrug-resistant MCF-7 /MX cells enhances cell adhesion to the extracellular matrix. Neoplasia 2008, 10:1275-1284.

136. Liu F, Fan D, Qi J, Zhu H, Zhou Y, Yang C, Zhu Z, Xiong D: Co-expression of cytokeratin 8 and breast cancer resistant protein indicates a multifactorial drug-resistant phenotype in human breast cancer cell line. Life Sci 2008, 83:496-501.

137. Ditzel HJ, Strik MC, Larsen MK, Willis AC, Waseem A, Kejling K, Jensenius JC Cancer-associated cleavage of cytokeratin $8 / 18$ heterotypic complexes exposes a neoepitope in human adenocarcinomas. J Biol Chem 2002, 277:21712-21722.

138. Pfaff M, O'Connor R, Vollmers HP, Muller-Hermelink HK: Human monoclonal antibody against a tissue polypeptide antigen-related protein from a patient with a signet-ring cell carcinoma of the stomach. Cancer Res 1990, 50:5192-5198.

139. Gires O, Munz M, Schaffrik M, Kieu C, Rauch J, Ahlemann M, Eberle D, Mack B, Wollenberg B, Lang S, et al: Profile identification of disease-associated humoral antigens using AMIDA, a novel proteomics-based technology. Cell Mol Life Sci 2004, 61:1198-1207.

140. Le Naour F, Brichory F, Misek DE, Brechot C, Hanash SM, Beretta L: A distinct repertoire of autoantibodies in hepatocellular carcinoma identified by proteomic analysis. Mol Cell Proteomics 2002, 1:197-203.

141. Li L, Chen SH, Yu CH, Li YM, Wang SQ: Identification of hepatocellularcarcinoma-associated antigens and autoantibodies by serological proteome analysis combined with protein microarray. J Proteome Res 2008, 7:611-620.

142. Gharib TG, Chen G, Wang H, Huang CC, Prescott MS, Shedden K, Misek DE, Thomas DG, Giordano TJ, Taylor JM, et al: Proteomic analysis of cytokeratin isoforms uncovers association with survival in lung adenocarcinoma. Neoplasia 2002, 4:440-448.

143. Yamashiro $Y$, Takei K, Umikawa M, Asato T, Oshiro M, Uechi Y, Ishikawa T, Taira K, Uezato H, Kariya K: Ectopic coexpression of keratin 8 and 18 
promotes invasion of transformed keratinocytes and is induced in patients with cutaneous squamous cell carcinoma. Biochem Biophys Res Commun 2010, 399:365-372.

144. Kabukcuoglu S, Ozalp SS, Yalcin OT, Colak E, Abubakar AA: Comparison of histopathologic classification and surgical stage by cytokeratin 8 and cytokeratin 18 in endometrial cancer. Eur J Gynaecol Oncol 2010, 31:641-644.

145. Schaafsma HE, Van Der Velden LA, Manni JJ, Peters H, Link M, Rutter DJ, Ramaekers FC: Increased expression of cytokeratins 8, 18 and vimentin in the invasion front of mucosal squamous cell carcinoma. J Pathol 1993, 170:77-86.

146. Warburg O, Wind F, Neglers E: The metabolism of tumors. London: Constable \& Co.; 1930

147. Crowther M, Brown NJ, Bishop ET, Lewis CE: Microenvironmental influence on macrophage regulation of angiogenesis in wounds and malignant tumors. J Leukoc Biol 2001, 70:478-490.

148. Lukashev D, Ohta A, Sitkovsky M: Hypoxia-dependent anti-inflammatory pathways in protection of cancerous tissues. Cancer Metastasis Rev 2007, 26:273-279.

149. Semenza GL: Hypoxia-inducible factor 1: oxygen homeostasis and disease pathophysiology. Trends Mol Med 2001, 7:345-350

150. Sedoris KC, Thomas SD, Miller DM: Hypoxia induces differential translation of enolase/MBP-1. BMC Cancer 2010, 10:157

151. Semenza GL, Jiang BH, Leung SW, Passantino R, Concordet JP, Maire P, Giallongo A: Hypoxia response elements in the aldolase A, enolase 1, and lactate dehydrogenase $A$ gene promoters contain essential binding sites for hypoxia-inducible factor 1. J Biol Chem 1996, 271:32529-32537.

152. Altenberg B, Greulich KO: Genes of glycolysis are ubiquitously overexpressed in 24 cancer classes. Genomics 2004, 84:1014-1020.

153. Cao L, Li X, Zhang Y, Peng F, Yi H, Xu Y, Wang Q: Proteomic analysis of human ovarian cancer paclitaxel-resistant cell lines. Zhong Nan Da Xue Xue Bao Yi Xue Ban 2010, 35:286-294.

154. Cappello P, Tomaino B, Chiarle R, Ceruti P, Novarino A, Castagnoli C, Migliorini P, Perconti G, Giallongo A, Milella M, et al: An integrated humoral and cellular response is elicited in pancreatic cancer by alpha-enolase, a novel pancreatic ductal adenocarcinoma-associated antigen. Int I Cancer 2009, 125:639-648.

155. Govekar RB, D'Cruz AK, Alok Pathak K, Agarwal J, Dinshaw KA, Chinoy RF, Gadewal N, Kannan S, Sirdeshmukh R, Sundaram CS, et al: Proteomic profiling of cancer of the gingivo-buccal complex: Identification of new differentially expressed markers. Proteomics Clin Appl 2009, 3:1451-1462.

156. Hamaguchi T, lizuka N, Tsunedomi R, Hamamoto Y, Miyamoto T, lida M, Tokuhisa Y, Sakamoto K, Takashima M, Tamesa T, Oka M: Glycolysis module activated by hypoxia-inducible factor 1alpha is related to the aggressive phenotype of hepatocellular carcinoma. Int J Oncol 2008, 33:725-731.

157. Hennipman A, Smits J, van Oirschot B, van Houwelingen JC, Rijksen G, Neyt JP, Van Unnik JA, Staal GE: Glycolytic enzymes in breast cancer, benign breast disease and normal breast tissue. Tumour Biol 1987, 8:251-263.

158. Katayama M, Nakano H, Ishiuchi A, Wu W, Oshima R, Sakurai J, Nishikawa H, Yamaguchi S, Otsubo T: Protein pattern difference in the colon cancer cell lines examined by two-dimensional differential in-gel electrophoresis and mass spectrometry. Surg Today 2006, 36:1085-1093.

159. Li C, Xiao Z, Chen Z, Zhang X, Li J, Wu X, Li X, Yi H, Li M, Zhu G, Liang S: Proteome analysis of human lung squamous carcinoma. Proteomics 2006, 6:547-558.

160. Lopez-Pedrera C, Villalba JM, Siendones E, Barbarroja N, Gomez-Diaz C, Rodriguez-Ariza A, Buendia P, Torres A, Velasco F: Proteomic analysis of acute myeloid leukemia: Identification of potential early biomarkers and therapeutic targets. Proteomics 2006, 6(Suppl 1):S293-299.

161. Mikuriya K, Kuramitsu Y, Ryozawa S, Fujimoto M, Mori S, Oka M, Hamano K, Okita K, Sakaida I, Nakamura K: Expression of glycolytic enzymes is increased in pancreatic cancerous tissues as evidenced by proteomic profiling by two-dimensional electrophoresis and liquid chromatography-mass spectrometry/mass spectrometry. Int J Oncol 2007, 30:849-855

162. Qi Y, Chiu JF, Wang L, Kwong DL, He QY: Comparative proteomic analysis of esophageal squamous cell carcinoma. Proteomics 2005, 5:2960-2971.

163. Shen J, Person MD, Zhu J, Abbruzzese JL, Li D: Protein expression profiles in pancreatic adenocarcinoma compared with normal pancreatic tissue and tissue affected by pancreatitis as detected by two-dimensional gel electrophoresis and mass spectrometry. Cancer Res 2004, 64:9018-9026.
164. Somiari Rl, Sullivan A, Russell S, Somiari S, Hu H, Jordan R, George A, Katenhusen R, Buchowiecka A, Arciero C, et al: High-throughput proteomic analysis of human infiltrating ductal carcinoma of the breast. Proteomics 2003, 3:1863-1873.

165. Takashima M, Kuramitsu Y, Yokoyama Y, lizuka N, Fujimoto M, Nishisaka T, Okita K, Oka M, Nakamura K: Overexpression of alpha enolase in hepatitis $C$ virus-related hepatocellular carcinoma: association with tumor progression as determined by proteomic analysis. Proteomics 2005, 5:1686-1692.

166. Tsai ST, Chien IH, Shen WH, Kuo YZ, Jin YT, Wong TY, Hsiao JR, Wang HP, Shih NY, Wu LW: ENO1, a potential prognostic head and neck cancer marker, promotes transformation partly via chemokine CCL20 induction. Eur J Cancer 2010, 46:1712-1723.

167. Tu SH, Chang CC, Chen CS, Tam KW, Wang YJ, Lee CH, Lin HW, Cheng TC, Huang CS, Chu JS, et al: Increased expression of enolase alpha in human breast cancer confers tamoxifen resistance in human breast cancer cells. Breast Cancer Res Treat 2010, 121:539-553.

168. Wong CS, Wong W, Chan CM, Ma BB, Hui EP, Wong MC, Lam MY, Au TC, Chan WH, Cheuk W, Chan AT: Identification of 5-fluorouracil response proteins in colorectal carcinoma cell line SW480 by two-dimensional electrophoresis and MALDI-TOF mass spectrometry. Oncol Rep 2008, 20:89-98.

169. Zhao J, Chang AC, Li C, Shedden KA, Thomas DG, Misek DE, Manoharan AP, Giordano TJ, Beer DG, Lubman DM: Comparative proteomics analysis of Barrett metaplasia and esophageal adenocarcinoma using twodimensional liquid mass mapping. Mol Cell Proteomics 2007, 6:987-999.

170. Zhou H, Chen CB, Lan J, Liu C, Liu XG, Jiang L, Wei F, Ma QJ, Dang GT, Liu ZJ: Differential proteomic profiling of chordomas and analysis of prognostic factors. J Surg Oncol 2010, 102:720-727.

171. Ito S, Honma T, Ishida K, Wada N, Sasaoka S, Hosoda M, Nohno T: Differential expression of the human alpha-enolase gene in oral epithelium and squamous cell carcinoma. Cancer Sci 2007, 98:499-505.

172. Chang GC, Liu KJ, Hsieh CL, Hu TS, Charoenfuprasert S, Liu HK, Luh KT, Hsu $\mathrm{LH}$, Wu CW, Ting CC, et al: Identification of alpha-enolase as an autoantigen in lung cancer: its overexpression is associated with clinical outcomes. Clin Cancer Res 2006, 12:5746-5754.

173. Suzuki A, lizuka A, Komiyama M, Takikawa M, Kume A, Tai S, Ohshita C, Kurusu A, Nakamura Y, Yamamoto A, et al: Identification of melanoma antigens using a Serological Proteome Approach (SERPA). Cancer Genomics Proteomics 2010, 7:17-23.

174. Chang YS, Wu W, Walsh G, Hong WK, Mao L: Enolase-alpha is frequently down-regulated in non-small cell lung cancer and predicts aggressive biological behavior. Clin Cancer Res 2003, 9:3641-3644.

175. Muller FL, Colla S, Aquilanti E, Manzo VE, Genovese G, Lee J, Eisenson D, Narurkar R, Deng P, Nezi L, et al: Passenger deletions generate therapeutic vulnerabilities in cancer. Nature 2012, 488:337-342.

176. Zhou W, Capello M, Fredolini C, Piemonti L, Liotta LA, Novelli F, Petricoin EF: Mass spectrometry analysis of the post-translational modifications of alpha-enolase from pancreatic ductal adenocarcinoma cells. J Proteome Res 2010, 9:2929-2936.

177. Hennipman A, van Oirschot BA, Smits J, Rijksen G, Staal GE: Glycolytic enzyme activities in breast cancer metastases. Tumour Biol 1988, 9:241-248.

178. Shih NY, Lai HL, Chang GC, Lin HC, Wu YC, Liu JM, Liu KJ, Tseng SW: Antialpha-enolase autoantibodies are down-regulated in advanced cancer patients. Jpn J Clin Oncol 2010, 40:663-669.

179. Mojtahedi Z, Safaei A, Yousefi Z, Ghaderi A: Immunoproteomics of HER2positive and HER2-negative breast cancer patients with positive lymph nodes. OMICS 2011, 15:409-418.

180. Sato N, Nabeta Y, Kondo H, Sahara H, Hirohashi Y, Kashiwagi K, Kanaseki T, Sato Y, Rong S, Hirai I, et al: Human CD8 and CD4 T cell epitopes of epithelial cancer antigens. Cancer Chemother Pharmacol 2000, 46(Suppl): s86-90.

181. Zou L, Wu Y, Pei L, Zhong D, Gen M, Zhao T, Wu J, Ni B, Mou Z, Han J, et al: Identification of leukemia-associated antigens in chronic myeloid leukemia by proteomic analysis. Leuk Res 2005, 29:1387-1391.

182. Huang LJ, Chen SX, Luo WJ, Jiang HH, Zhang PF, Yi H: Proteomic analysis of secreted proteins of non-small cell lung cancer. Ai Zheng 2006, 25:1361-1367

183. Dot C, Guigay J, Adamus G: Anti-alpha-enolase antibodies in cancerassociated retinopathy with small cell carcinoma of the lung. Am J Ophthalmol 2005, 139:746-747. 
184. He P, Naka T, Serada S, Fujimoto M, Tanaka T, Hashimoto S, Shima Y, Yamadori T, Suzuki H, Hirashima T, et al: Proteomics-based identification of alpha-enolase as a tumor antigen in non-small lung cancer. Cancer Sci 2007, 98:1234-1240

185. Tomaino B, Cappello P, Capello M, Fredolini C, Sperduti I, Migliorini P, Salacone P, Novarino A, Giacobino A, Ciuffreda L, et al: Circulating autoantibodies to phosphorylated alpha-enolase are a hallmark of pancreatic cancer. J Proteome Res 2011, 10:105-112.

186. Cappello P, Rolla S, Chiarle R, Principe M, Cavallo F, Perconti G, Feo S, Giovarelli M, Novelli F: Vaccination With ENO1 DNA Prolongs Survival of Genetically Engineered Mice With Pancreatic Cancer. Gastroenterology 2013.

187. Rehman I, Azzouzi AR, Catto JW, Allen S, Cross SS, Feeley K, Meuth M, Hamdy FC: Proteomic analysis of voided urine after prostatic massage from patients with prostate cancer: a pilot study. Urology 2004, 64:1238-1243

188. Forgber M, Trefzer U, Sterry W, Walden P: Proteome serological determination of tumor-associated antigens in melanoma. PLoS One 2009, 4:e5199.

189. Seweryn E, Pietkiewicz J, Bednarz-Misa IS, Ceremuga I, Saczko J, Kulbacka J, Gamian A: Localization of enolase in the subfractions of a breast cancer cell line. Z Naturforsch C 2009, 64:754-758.

190. Mears R, Craven RA, Hanrahan S, Totty N, Upton C, Young SL, Patel P, Selby PJ, Banks RE: Proteomic analysis of melanoma-derived exosomes by twodimensional polyacrylamide gel electrophoresis and mass spectrometry. Proteomics 2004, 4:4019-4031.

191. Yu X, Harris SL, Levine AJ: The regulation of exosome secretion: a novel function of the p53 protein. Cancer Res 2006, 66:4795-4801.

192. Saldanha RG, Molloy MP, Bdeir K, Cines DB, Song X, Uitto PM, Weinreb PH, Violette SM, Baker MS: Proteomic identification of lynchpin urokinase plasminogen activator receptor protein interactions associated with epithelial cancer malignancy. J Proteome Res 2007, 6:1016-1028.

193. Trojanowicz B, Winkler A, Hammje K, Chen Z, Sekulla C, Glanz D, Schmutzler C, Mentrup B, Hombach-Klonisch S, Klonisch T, et al: Retinoic acidmediated down-regulation of ENO1/MBP-1 gene products caused decreased invasiveness of the follicular thyroid carcinoma cell lines. J Mol Endocrinol 2009, 42:249-260.

194. Dowling P, Meleady P, Dowd A, Henry M, Glynn S, Clynes M: Proteomic analysis of isolated membrane fractions from superinvasive cancer cells. Biochim Biophys Acta 2007, 1774:93-101.

195. Zitvogel L, Tesniere A, Kroemer G: Cancer despite immunosurveillance: immunoselection and immunosubversion. Nat Rev Immunol 2006, 6:715-727.

196. Disis ML, Pupa SM, Gralow JR, Dittadi R, Menard S, Cheever MA: High-titer HER-2/neu protein-specific antibody can be detected in patients with early-stage breast cancer. J Clin Oncol 1997, 15:3363-3367.

197. Kondo H, Sahara H, Miyazaki A, Nabeta Y, Hirohashi Y, Kanaseki T, Yamaguchi A, Yamada N, Hirayama K, Suzuki M, et al: Natural antigenic peptides from squamous cell carcinoma recognized by autologous HLADR8-restricted CD4+ T cells. Jpn J Cancer Res 2002, 93:917-924.

doi:10.1186/2162-3619-2-12

Cite this article as: Ceruti et al:: Three are better than one: plasminogen receptors as cancer theranostic targets. Experimental Hematology \& Oncology 2013 2:12

\section{Submit your next manuscript to BioMed Central and take full advantage of:}

- Convenient online submission

- Thorough peer review

- No space constraints or color figure charges

- Immediate publication on acceptance

- Inclusion in PubMed, CAS, Scopus and Google Scholar

- Research which is freely available for redistribution 